\title{
STRATIGRAPHIC CHANGE OF THE COARSE CLASTIC ROCKS OF THE SHIMANTO SUPERGROUP IN EASTERN, SHIKOKU, SOUTHWEST JAPAN
}

\author{
Fujio KUMON \\ Department of Geology, Faculty of Science, Shinshu University, \\ Matsumoto, Japan
}

\begin{abstract}
The Shimanto Supergroup of geosynclinal facies which ranges from Cretaceous to early Tertiary in age, is widely distributed in the outermost zone of Southwest Japan. Coeval volcanic and plutonic rocks are extensively distributed in the Inner Zone. The coarse clastic rocks mainly of sandstone occupy about a half of the Shimanto Supergroup, and a stratigraphic change of sandstone and conglomerate composition is recognized in the supergroup. The amount of rock fragments, chiefly acidic to intermediate volcanic rocks, increases upward throughout the Cretaceous sequence. Additionally, acidic tuff layers are frequently intercalated in the Late Cretaceous sequence. Conglomerates in the Late Cretaceous are very dominated by acidic volcanic rock clasts. The geosynclinal sedimentation of the Cretaceous Shimanto Supergroup proceeded with the coeval volcanism which became more active in the Late Cretaceous. The clastic sediments were supplied mainly from the sites of the volcanism. The volcanism corresponds to the Cretaceous volcanic activity in the Inner Zone of Southwest Japan. The Cretaceous Shimanto Supergroup may represent a typical forearc sedimentation in an arc-trench system.
\end{abstract}

\section{Introduction}

The Shimanto Belt occupying the outermost zone of Southwest Japan, consists of a large amount of geosynclinal sediments called the Shimanto Supergroup, ranging from early Cretaceous to early Miocene in age (Fig. 1). Coeval volcanic and plutonic rocks of acidic to intermediate composition are widely distributed in the Inner Zone. Recently, some authors con- 


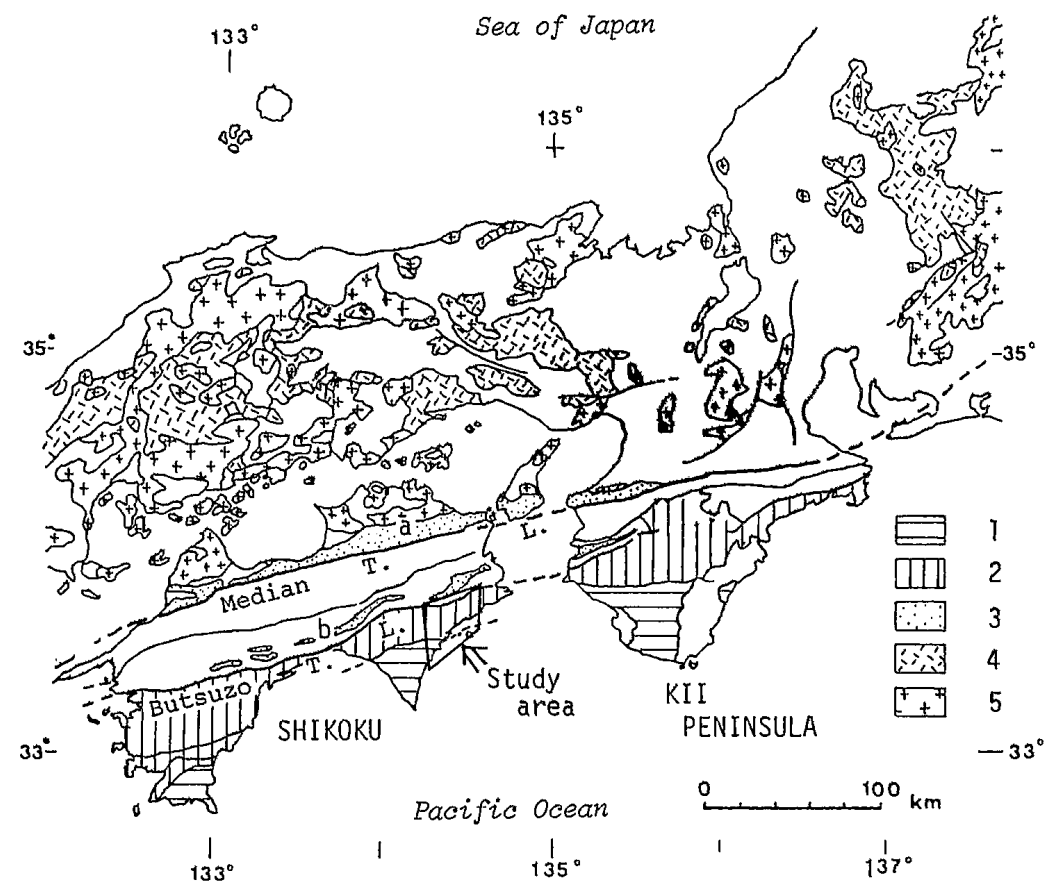

Fig. 1. Index map of the study area showing also the distribution of Cretaceous sediments and Cretaceous to Paleogene ingeous rocks. $1 \cdot 2$. Shimanto Belt (1. early Tertiary, 2. Cretaceous), 3. Cretaceous shallower sediments (a. Izumi G., b. Cretaceous in the Chichibu Belt), 4. Cretaceous to Paleogene volcanic rocks, 5. Cretaceous to Paleogene plutonic rocks.

sidered that this region was the site of consumption of the oceanic plate (KanMera and SAKaI, 1975; SuzuKI and HAdA, 1979; Dickinson, 1977; TAIRA et al., 1980). In the supergroup, coarse clastic rocks such as sandstone and conglomerate occupy one-third to a half of the total sediments by volume. The composition of coarse clastic rocks should offer important information on the provenance and crustal movements especially in relation to igneous activity in the Inner Zone.

The study area, the eastern margin of eastern Shikoku, is located in the central portion of the Shimanto Belt, and the strata exposed in this area have suffered less metamorphism and tectonic disturbance than those of other areas. Furthermore, sandstone and conglomerate are well developed. The stratigraphy and detailed description of coarse clastic rocks had already reported by the author (KUMON, 1981, 1983). In this paper, the author will discuss mainly the geologic significance of the upwardincreasing trend of rock fragments in sandstone throughout the Cretaceous 
sequence.

\section{Geology}

The Shimanto Belt in eastern Shikoku is divided by the Aki Fault into northern and southern subbelts. The Cretaceous strata of eugeosynclinal facies are distributed in the northern subbelt, and the early Tertiary of flysch facies occupy the southern subbelt (Fig. 2). The northern subbelt is subdivided by two strike faults into three zones, namely the northern, central and southern zones, each represented mainly by the Akamatsu and Hinotani Formations, Taniyama Formation, and Mugi and Hiwasa Formations, respectively. The southern subbelt is also subdivided by two strike faults into three zones, each represented by the Kaifu, Naharigawa and Muroto Formations from north to south.

The geologic age of the Cretaceous has been fairly well determined by radiolarian fossils as shown in Fig. 3. The Akamatsu Formation, about 1,500 meters thick, is dominated by muddy rocks accompanied by sand-

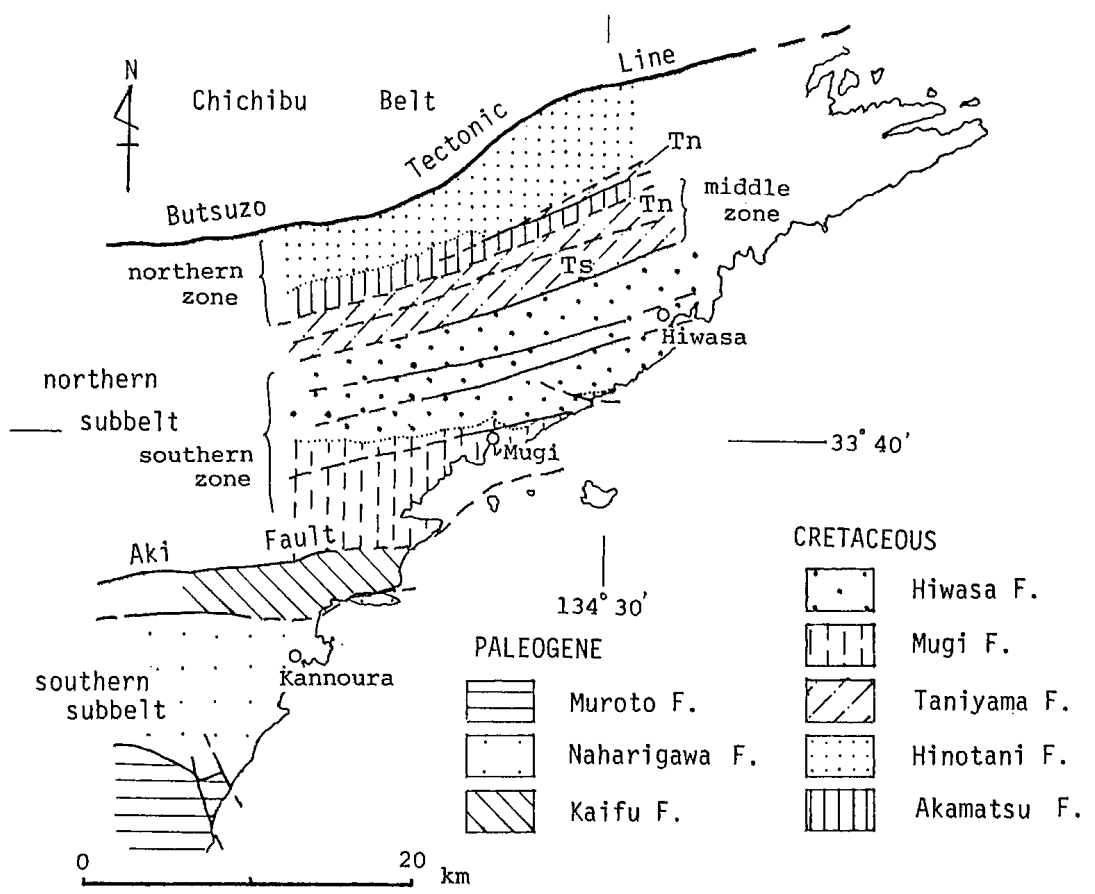

Fig. 2. Geologic map of the Shimanto Belt in eastern margin of eastern Shikoku. 


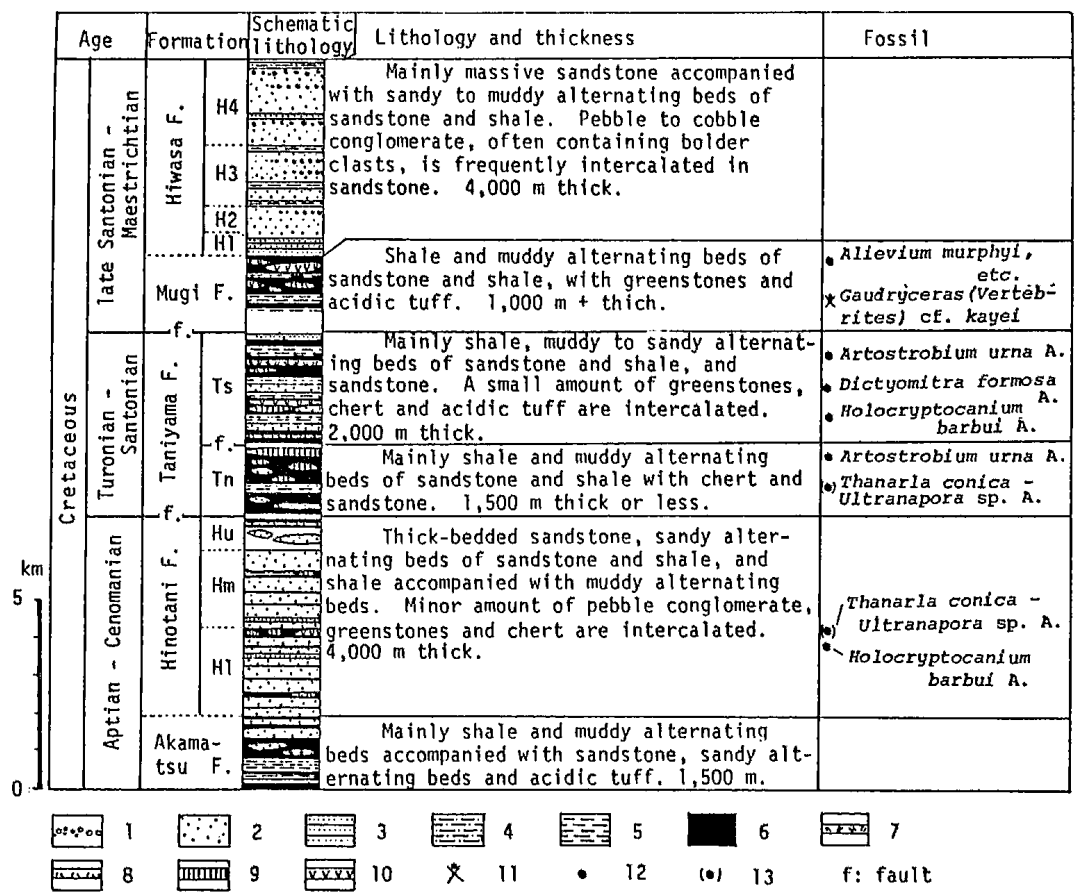

Fig. 3. Generalized geological column with respect to the Cretaceous strata of the Shimanto Supergroup in eastern Shikoku. After KUMON (1983). Fossil data are based on SUYARI et al. (1967), NAKagawa et al. (1980) and KUMON (1983 and unpub. data). 1. conglomerate, 2. sandstone, 3. sandy alternations, 4. normal alternations, 5. muddy alternations, 6. shale, 7. acidic tuff, 8. tuffaceous shale, 9. chert, 10. greenstones, 11. megafossil, 12. microfossil, 13. derived microfossil.

stone and alternating beds of sandstone and shale. The Hinotani Formation, conformably overlying the Akamatsu Formation, consists chiefly of thick-bcdded sandstone, alternating beds of sandstone and shale, and shale, rarely accompanied by pebble conglomerate, greenstones and chert. Its thickness is about 4,000 meters. The Akamatsu and Hinotani Formations are assigned to an Aptian to Cenomanian age range, on the basis of the occurrence of radiolarian fossils of Holocryptocanium barbui Assemblage* (late Albian to Cenomanian).

The Taniyama Formation, about 2,000 meters thick, is composed mainly of muddy rocks accompanied by sandstone, chert, acidic tuff and

*The zonation and name of the radiolarian assemblages follow those proposed by MATSUYAMA et al. (1982). 
greenstones. Its northern half $(\mathrm{Tn})$ is fairly abundant in chert, and in contrast the southern half (Ts) is relatively rich in sandstone and acidic tuff. The precise relation between the two parts remains uncertain. The genuine age of this formation is inferred to be Turonian to Santonian, judging from the occurrences of a Dictyomitra formosa Assemblage (Turonian) and an Artostrobium urna Assemblage (Coniacian to Santonian) in the tuffaceous and black shales, although Tithonian to Cenomanian radiolarian assemblages were also discovered at places, derived from chert and red shale of exotic origin in this formation.

The Mugi Formation, more than 1,000 meters thick, mostly consists of muddy rocks associated with greenstones, acidic tuff and sandstone. The Hiwasa Formation which conformably overlies the Mugi Formation, is mainly represented by conglomerate, massive sandstone, and alternating beds of sandstone and shale. It is about 4,000 meters thick. The Mugi Formation is assigned to a late Santonian to Campanian age range on the basis of the occurrences of Gaudryceras (Vertebrites) sp. cf. kayei and Coniacian to Campanian radiolarian fossils (SUYARI et al., 1967; KUMON, 1981). The Hiwasa Formation is estimated to be Campanian to Maestrichtian in age, judging from its great thickness.

The geological age of each zone becomes younger southward. The main depositional site may have migrated southward step by step. Homoclinal structure is dominant in each zone, although frequently faulted and occasionally folded.

According to KUMON (1983), it was considered that most of the clastic sediments of Cretaceous age were transported by longitudinal currents from west to east or from east to west and by lateral currents from north to south, with the major source land situated to the north of the basin. One exception is the Nyunokawa Formation in the Kii Peninsula which seems to have recieved clastic sediments from a southern land source (KISHU Shimanto Research Group, 1977; Harata et al., 1979).

\section{Conglomerate}

Conglomerate composition gives detailed information on the source rocks. The compositions of the conglomerates in the Cretaceous are shown in Fig, 4.

Several beds of pebble conglomerate, 0.5 to 1 meter thick, are intercalated in the Middle Member of the Hinotani Formation (Hm Mem.). The clasts of conglomerate are mostly granule to fine pebble in size and rounded to subrounded in shape. Sedimentary rocks such as sandstone, shale, chert and muddy limestone occupy more than a half of the total 


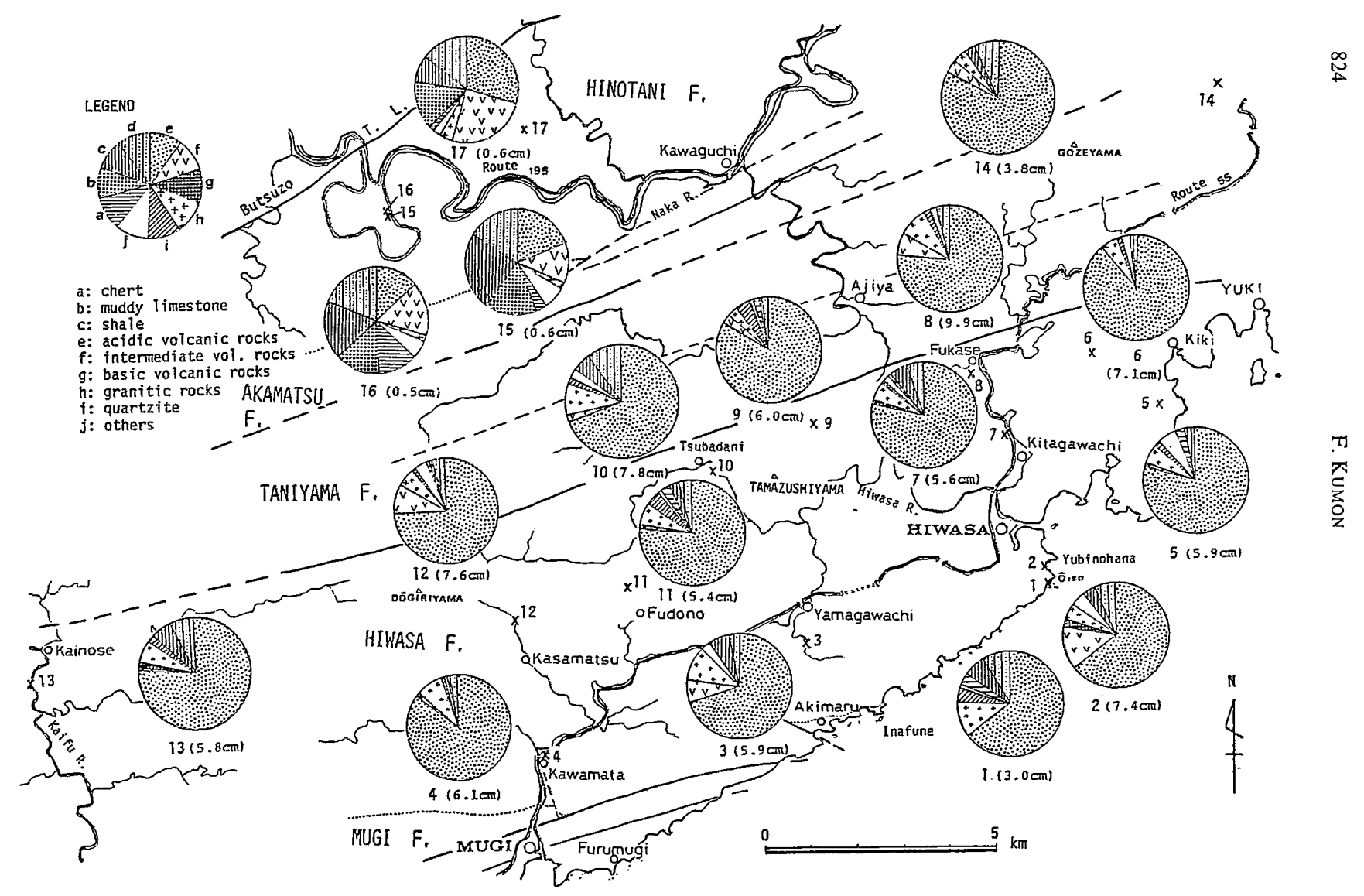

Fig. 4. Conglomerate composition of the Cretaceous Shimanto Supergroup in eastern Shikoku (after KUMON, 1981). 
composition, and acidic and intermediate volcanic rocks occupy about one-fifth.

Only one bed of pebble conglomerate is intercalated in the Taniyama Formation. The clasts are mostly coarse pebble sized, rounded to subrounded, and scattered in muddy matrix. Acidic volcanic rock clasts are very dominant.

The conglomerates of the Hiwasa Formation are usually 1 to 10 meters thick, and rarely up to 100 meters. The clasts are mostly pebble to cobble sized, and rounded to subrounded. Boulder clasts are sometimes contained in them. Acidic volcanic rocks, namely rhyolite lava and tuff, are very predominant in the clasts. Clasts of welded rhyolite tuff are frequently found in them. Clasts of granitic rocks, sandstone and shale are commonly contained, but are small in amount.

\section{Sandstone}

Sandstone is one of the most dominant rocks of the Shimanto Supergroup, and can be examined successively throughout the geologic succession. Therefore, the mineral composition of sandstone is more useful than the conglomerate composition in discussing successive crustal movements in the hinterland.

In this study, specimens for examination were taken from massive, medium- to coarse-grained sandstone beds thicker than 0.5 meter. The modal composition was obtained by the counting more than 500 points in one thin-section for each specimen under the microscope (grid spacing $0.5 \times 1$ $\mathrm{mm}$ ). The constituents are divided into monocrystalline quartz, polycrystalline quartz, plagioclase, potash feldspar, rock fragments of various kinds, "matrix" (including calcite and other silicate cements, and the grains smaller than $0.03 \mathrm{~mm}$ ), and others consisting of heavy minerals, shale patches, etc.

The results are shown in Fig. 5. As for the rock fragments in sandstone, a special examination was made on several selected specimens which are supposed to have nearly average mineral compositions for each formation (Fig. 6). Most of the Cretaceous sandstones have more than 15 per cent matrix, and belong to a lithic or feldspathic graywacke classification. The framework grains are mostly angular to subrounded, and are moderately to well sorted. The difference between the mineral compositions of the sandstones can be clearly recognized among the formations.

Sandstones of the Akamatsu and Hinotani Formations are dominated by both plagioclase and potash feldspar, especially by plagioclase, and are poor in rock fragments. Intermediate volcanic rocks and granitic rocks 


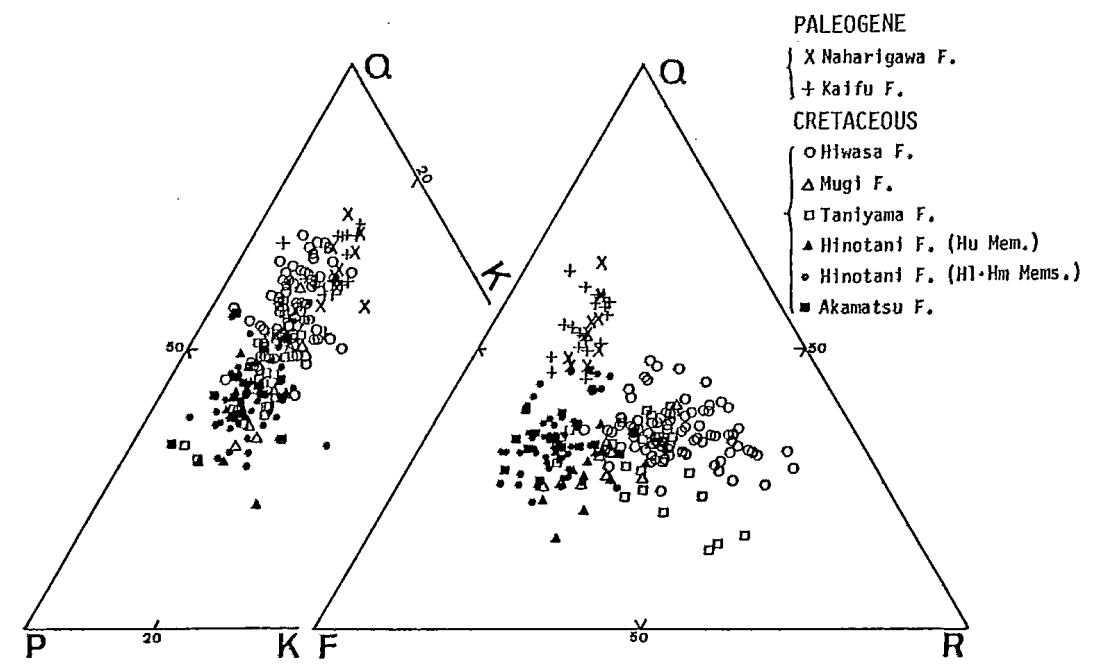

Fig. 5. Triangular $Q-F-R$ and $Q-P-K$ plots of the sandstone compositions from the Shimanto Supergroup in eastern Shikoku (after KUMON, 1983).

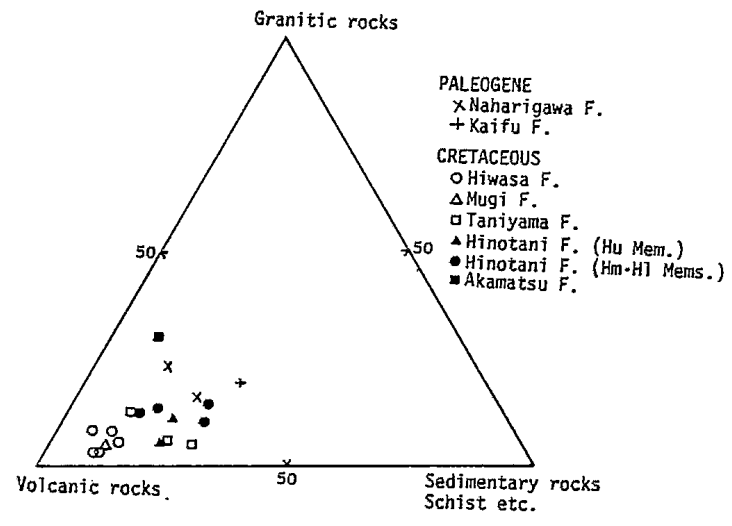

Fig. 6. Triangular plots of partial mode of rock fragments for selected sandstone specimens which are supposed to have nearly average compositions for each formation.

comprise a relatively large part of the rock fragments component, although acidic volcanic rocks are most abundant. Sedimentary rock fragments such as shale and chert are also commonly contained. In the Upper Member of the Hinotani Formation ( $\mathrm{Hu}$ Mem.), the amount of rock fragments increases a little. 
Sandstones of the Taniyama Formation are rich in rock fragments and relatively poor in feldspar. Some specimens are very poor in quartz. In the rock fragments component, acidic volcanic rocks are predominant, and sedimentary rocks such as shale and chert, and schistose rocks are commonly contained.

Sandstone of the Mugi Formation are fairly abundant in both feldspar and rock fragments, and seems to have an intermediate nature between those of the Hinotani Formation and the Hiwasa Formation described below.

Sandstones of the Hiwasa Formation are mainly dominated by rock fragments. Acidic volcanic rocks are predominant in the rock fragments component, and intermediate volcanics are also commonly contained in it. The sandstones of the lower part of the Hiwasa Formation (H2 Mem.) are relatively poor in rock fragments, however.

Compared with the Cretaceous sandstones, the early Tertiary sandstones are heavily dominated by quartz, and are poor in rock fragments and matrix (Fig. 4). They mostly belong to an arkose, and partly to an arkosic wacke classification. No significant difference of sandstone composition can be recognized between the Kaifu and Naharigawa Formations.

\section{Implications of the Stratigraphical Change of Clastic Rock Composition}

The Cretaceous sandstone and conglomerate contain fairly abundant volcanic clasts and fragments of acidic to intermediate composition (Figs. 4,5 , and 6). It is of particular interest that there is a distinct upward increase in the content of rock fragments, consisting chiefly of acidic to intermediate volcanic rocks, in the Cretaceous sequence, although with some fluctuations, however (Fig. 7). The ratio of volcanic rocks also increases upward in the rock fragments component. The conglomerates of the Late Cretaceous become predominated by acidic volcanic rocks which consist of rhyolite lava and often welded rhyolite tuff. From these facts it is concluded that compositional differences are related to the stratigraphic formations of the Cretaceous sandstones, as examined at various places in the Shimanto Belt (ToKUOKA and Kumon, 1979; МiYAMOTO, 1976; TERAOKA, 1977; OKADA, 1977; etc.). Unfortunately, the geologic age of the sandstones examined are not very reliable in most caces, because of the lack of fossil evidence. The author, however, is positive that the stratigraphic change in sandstone composition can be roughly applied to the Cretaceous throughout the Shimanto Belt, because there is a tendency for sandstones in the northern zone of the Cretaceous subbelt to be rich in feldspar and poor in rock fragments, and in contrast those in the southern 


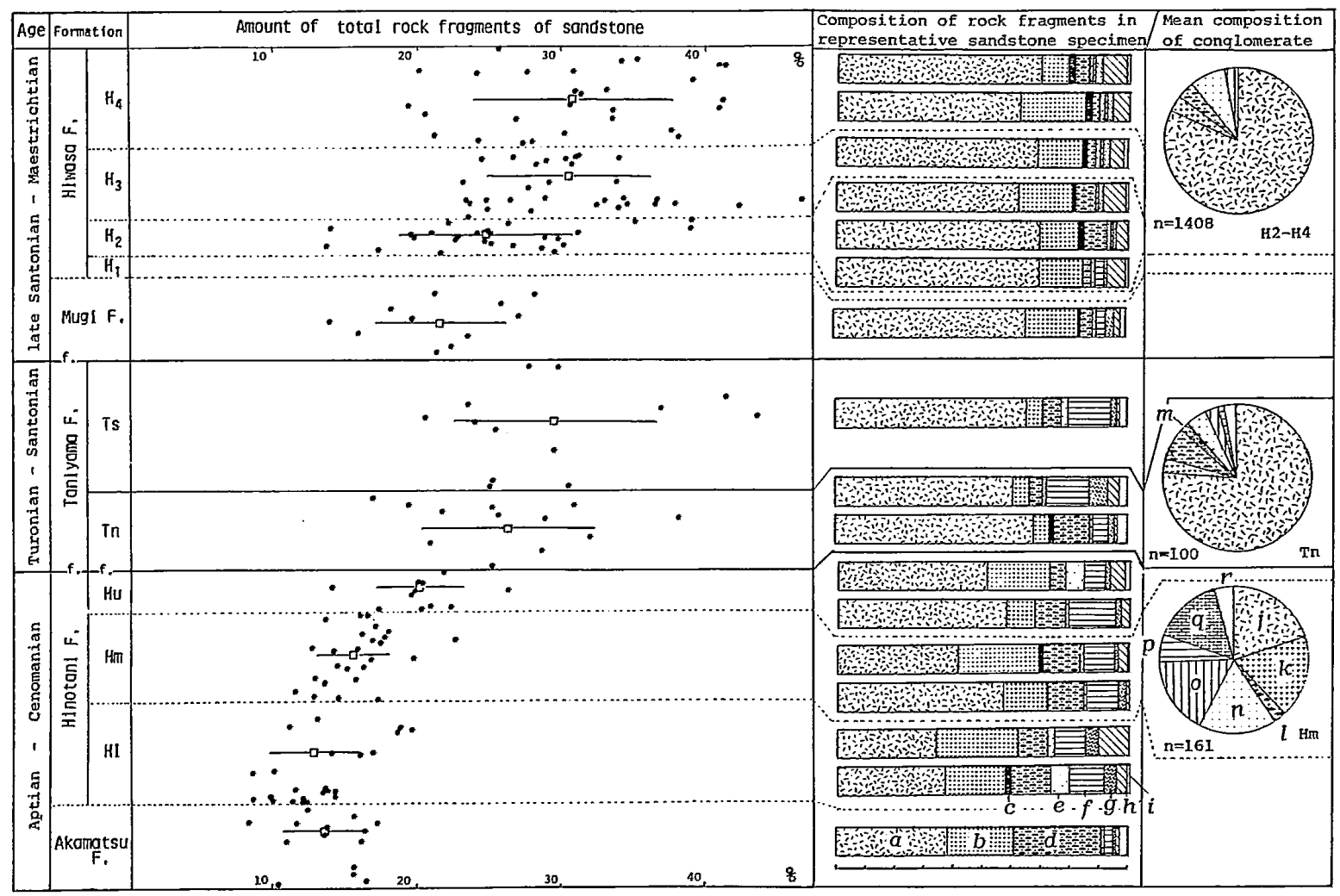

Fig. 7. Increasing trend of the rock fragments in the Cretaceous Shimanto Supergroup in eastern Shikoku, showing also stratigraphic change of conglomerate composition (after KUMON, 1983). Open square is the mean of each formation or member, and the bar means standard deviation. Key are as follows: a.j. acidic volcanic rocks, b-k. intermediate volcanic rocks, c·m. basic volcanic rocks, $d \cdot l$. sandstone, f•o. shale, $g \cdot p$. chert, h. hornfels-like rocks, i. schistose rocks, q. muddy limestone, r. others. 
part to be rich in rock fragments consisting mainly of volcanic rocks, The strata in the Cretaceous subbelt seem to become younger southward zone by zone, as the cases of eastern Shikoku and Kii Peninsula show (KumON, 1983).

The mineral composition of the Cretaceous sandstones from the median zone of Southwest Japan, that is, from the Onogawa Group in western Kyushu and the Izumi Group in Shikoku are shown in Fig. 8. Sandstones of the Onogawa Group ranging from Cenomanian to Santonian in age are feldspathic, but contain considerable amounts of rock fragments in which acidic to intermediate volcanic rocks occupy about 60 per cent by volume (TERAOKA, 1977). Sandstones of the Izumi Group ranging from Campanian to Maestrichtian in age, are rich in rock fragments in which volcanic rocks occupy 80 to 90 per cent by volume (NisHIMURA, 1976; TERAOKA, 1977). This change of sandstone composition from the Onogawa Group to Izumi Group is concordant with the stratigraphic change of sandstone composition clarified in the Cretaceous Shimanto Supergroup, resulting from the change of the provenance nature.

As mentioned by KUMON (1983), it is probable that violent volcanic activity in the hinterland took place in the Late Cretaceous age, and the volcanic products had a wide land cover. The volcanism should have produced a high topographic relief, and extensively destroyed the vegetational land cover. These factors would significantly increase the production of clastic sediments consisting cheifly of volcanic rocks (for modern example, KUENZI et al., 1979). The clastic sediments of the Shimanto Belt had

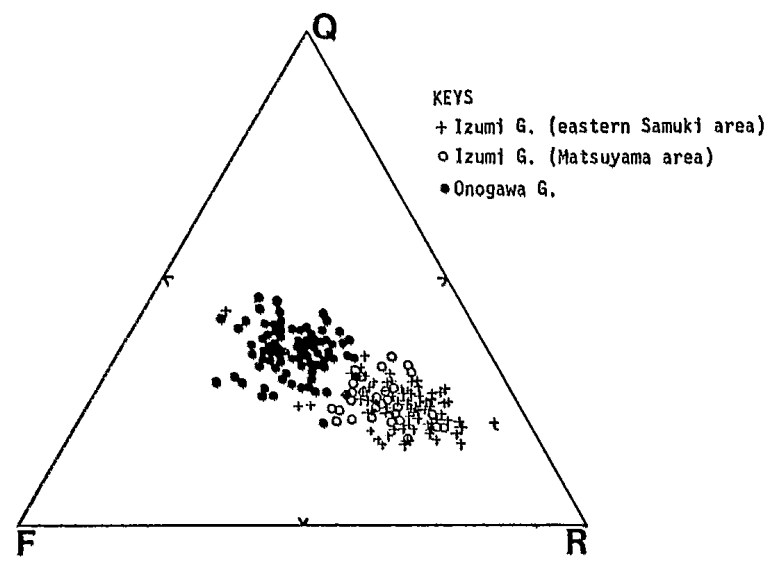

Fig. 8. Triangular $Q-F-R$ plots of the sandstone compositions from the Cretaceous in the median zone of Southwest Japan. Compiled from TERAOKA (1977) and NiSHIMURA (1976). 
been derived mainly from such volcanic sites, and hence formed a thick sequence. Violent volcanism seems to have begun in late Cenomanian or Turonian times, judging from the increasing proportion of rock fragments. Acidic tuffs which are medium-to coarse-grained and attain to several meters in thickness, are often intercalated in the Upper Cretaceous deposits. This fact also supports the existance of active volcanism near the basin.

It is evident that the sedimentation of the Late Cretaceous Shimanto Supergroup in eastern Shikoku had progressed contemporaneously with the violent volcanism in the hinterland, receiving much clastic sediment from the sites of volcanism.

\section{Discussion}

A similar stratigraphic change of sandstone composition mentioned above can be recognized in the Cretaceous Shimanto Supergroup in the Kii Peninsula (KUMON, 1983). The model composition in the supergroup is also similar, although the time of the increase of volcanic rock fragments may be somewhat different.

According to Mryamoto (1980), the regular stratigraphic change of sandstone composition is not so distinct in the Cretaceous sequences in the Chichibu Belt as that in the Shimanto Belt. The volcanic rock clasts and fragments, however, definitely increase in the Coniacian to Santonian strata, as represented by the Sotoizumi Group.

Therefore, the Cretaceous strata distributed in Southwest Japan should be regarded as the sediments formed during progressively greater volcanic activity in the hinterland. The volcanism probably corresponds to the wellknown Cretaceous volcanic activity in the Inner Zone of Southwest Japan.

An intimate relationship between the sedimentation in the basin and the volcanism in the hinterland is found in the arc-trench system. For example, the clastic sediments of the Great Valley sequence in California ranging in age from late Iurassic to Late Cretaceous, were supplied from the Sierra Nevada magmatic arc to the east, during the same period (DICKINSON and RICH, 1972; INGERSOLL, 1979; MANSFIELD, 1979; and others). DiCKINSON and SEELY (1979) regarded it as a typical example of the forearc sediments in an arc-trench system. In the case of the Great Valley sequence, however, the amount of volcanic rock fragments in sandstone decreases upward as a whole. This fact indicates that the main volcanism in the source land had already ended before the major sedimentation took place in the basin. They also explained it as the result of an unroofing and dissecting process of the Sierra Nevada magmatic arc. It is important that the sedimentation of the Cretaceous in Southwest Japan 
proceeded with the contemporaneous volcanism in the hinterland, as represented by the Cretaceous Shimanto Supergroup. In the other words, the sedimentation of the Cretaceous had corresponded to the "roofing" process by volcanic rocks in magmatic terrane. The transition from the Cretaceous to the early Tertiary Shimanto Supergroup may be compared with the stratigraphic change in the Great Valley sequence (KUMON, 1983).

Recently, NaKaZawa et al. (1983) and Kishu Shimanto ReSEarch GrouP (in preparation) elucidated that in the Kii Peninsula, the Turonian to Santonian strata intercalate with the chert-greenstone olistostromes among the usual flysch units. They considered that the both sediments were formed in a trench or lower continental slope, and that the chert and greenstone were derived from submarine volcanic seamounts to the south. The Taniyama Formation in eastern Shikoku is correlative with
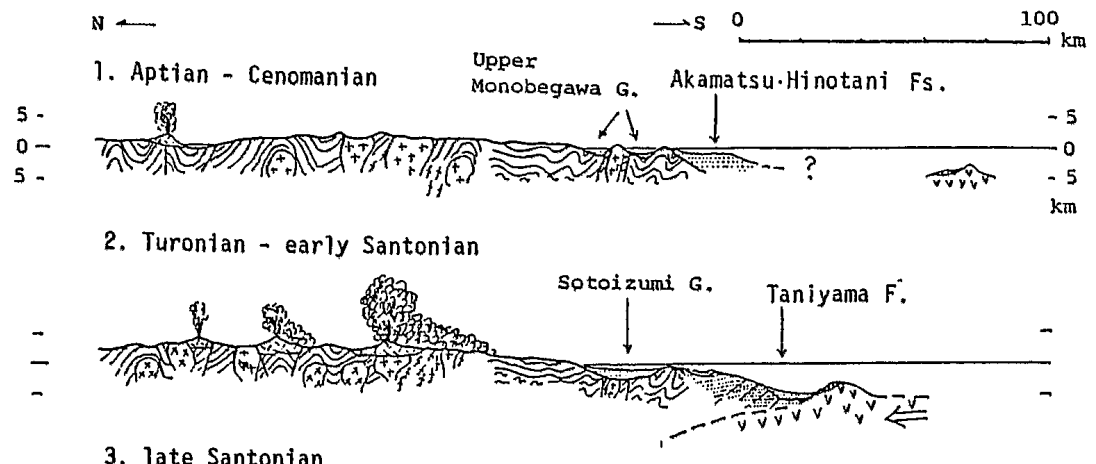

3. late Santonian
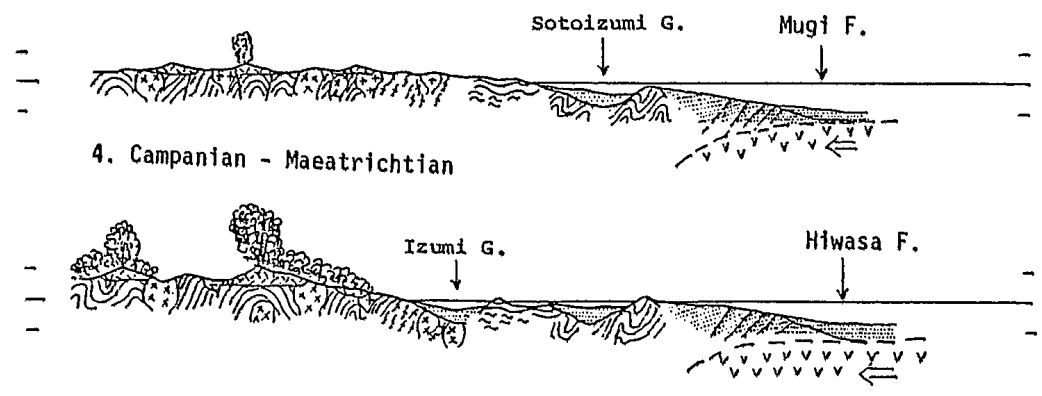

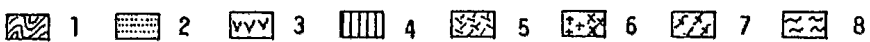

Fig. 9. Schematic cross sections of the Shimanto basin and its hiterland during the Cretaceous. The figures are illustrated as typical ones in each stage. 1. Paleozoic to early Mesozoic strata, 2. Cretaceous sediments, 3. greenstones, 4. chert, 5. acidic to intermediate volcanic rocks, 6. granitic rocks, 7. gneiss, 8 . schist. 
the strata, and also contains chert and greenstones of exotic origin. Similar opinions were mentioned by SUZUKI and HADA (1979) and TAIRA et al. (1980).

Therefore, the Shimanto basin and its hinterland seems to have formed an arc-trench system at least during the Late Cretaceous time. On the above-mentioned facts, tentative evolutional history of the Cretaceous Shimanto basin and its hinterland is illustrated schematically in Fig. 9.

\section{Acknowledgements}

The author would like to thank K. NAKAZAwA, Emeritus Professor of Kyoto University, and Dr. T. ToKUOKA of Shimane University for their helpful supervision and encouragements. He is also obliged to the members of the KISHU SHIMANTO RESEARCH GROUP who made valuable discussions with the author. The instruction of radiolarian fossil was received from Dr. K. NAKASEKO of Osaka University. Many thin-sections were prepared by Messrs. H. TsursumI and K. YosHIDA of Kyoto University. The author wishes to heartily thank them.

\section{REFERENCES}

DICKINSON, W. R., Subduction tectonics in Japan, EOS, 58, 948-952, 1977.

DICKINSON, W. R. and E. I. RICH, Petrologic intervals and petrofacies in the Great Valley Sequece, Sacramento Valley, California, Geol. Soc. Am. Bull., 83, 3007-3024, 1972.

DiCKINSON, W. R. and D. R. SEely, Structure and stratigraphy of forearc regions, $A m$. Assoc. Petrol. Geol. Bull., 63, 2-31, 1979.

harata, T., K. Hisatomi, F. Kumon, K. Nakazawa, M. Tateishi, H. Suzuki, and T. TOKUOKA, Shimanto geosyncline and Kuroshio Paleoland, Phys. Earth, 26, Suppl., 357-366, 1979.

INGERSOLL, R. V., Evolution of the Late Cretaceous forearc basin, northern and central California, Geol. Soc. Am. Bull., Part I, 90, 813-826, 1979.

KANMERA, K. and T. SaKaI, Correspondence of the formation place of the Shimanto Group to the present sea-floor, GDP Rep. II-I (I). Struc. Geol., No.3, 55-64, 1975.

KisHU SHIMANTO RESEARCH GROUP, The Hidakagawa Group in the southern part of Ryujin Village, Wakayama Prefecture-the study of the Shimanto Terrain in the Kii Peninsula, Southwest Japan (Part 8), Earth Sci. (Chikyu Kagaku), 31, 250-262, 1977.

KuENzI, W. D., O. H. Horst, and R. V. MCGeHEE, Effect of volcanic activity on fluvialdeltaic sedimentation in a modern arc-trench gap, southwestern Guatemala, Geol. Soc. Am. Bull. Part I, 90, 827-838, 1979.

KUMON, F., Shimanto Supergroup in the southern part of Tokushima Prefecture, Southwest Japan, Geol. Soc. Japan, 87, 277-295, 1981.

KUMON, F., Coarse clastic rocks of the Shimanto Supergroup in eastern Shikoku and Kii Peninsula, Southwest Japan, Mem. Fac. Sci., Kyoto Univ., Ser. Geol. Min., 49, 63-109, 1983.

MANSFIELD, C. F., Upper Mesozoic subsea fan deposits in the southern Diablo Range, California: record of the Sierra Nevada magmatic arc, Geol. Soc. Am. Bull., Part I, 90, 1025-1046, 1979.

Matsuyama, H., F. KUMON, and K. NAKAJo, Cretaceous radiolarian fossils from the 
Hidakagawa Group in the Shimanto Belt, Kii Peninsula, Southwest Japan, News, Osaka Micropaleont. Assoc,, Spec. Pub., No, 5, 371-382, 1982.

MiYAmoto, T., Comparison of the Cretaceous sandstones from the Chichibu and Shimanto Terrains in the Odochi area, Kochi Prefecture, Shikoku, Geol. Soc. Japan, 82, 449-462, 1976.

MIYAMото, T., Stratigraphical and sedimentlogical studies of the Cretaceous System in the Chichibu Terrain of the Outer Zone of Southwest Japan, Sci., Hiroshima Univ., Ser. C, No. 3, 1-139, 1980.

NAKAGAWA, C., K. NAKASEKo, K. KAWAGUCHI, and R. YoshImURA, Radiolarian fossils (from Upper Jurassic to Upper Cretaceous) of the northern zone of the Shimanto Supergroup-the study of the Shimanto Supergroup in eastern Shikoku, part 4, Gakugei, Tokushima Univ., Nat. Sci., 31, 1-27, 1980.

NAKASEKo, K., A. NiSHIMURA, and K. SUgANO, Study on radiolarian fossils of the Shimanto Belt, News, Osaka Micropaleont. Assoc., Spec. Pub., No. 2, 1-49, 1979.

Nakazawa, K., F. Kumon, K. Kimura, H. Matsuyama, and K. Nakajo, Sedimentary environment of the Cretaceous cherts in the Shimanto Belt, Kii Peninsula, Southwest Japan, in Siliceous Deposits in the Pacific Region, edited by IIJIMA, A., J. R. HeIn, and R. SIEVER, pp. 395-411, Elsevier, Amsterdam, 1983.

Nishimura, T., Petrography of the Izumi sandstones in the east of the Sanuki Mountain Range, Shikoku, Japan, Geol. Soc, Japan, 82, 231-240, 1976.

OKaDA, H., Preliminary study of sandstones of the Shimanto Supergroup in Kyushu, with special reference to "petrographic zone", Sci. Rep., Geology Kyushu Univ., 12, 203-214, 1977.

SUYARI, K., Y. BANDO, and I. OBATA, Discovery of a Cretaceous ammonite from the Shimanto Belt in Mugi-cho, Tokushima Prefecture, Geol. Soc. Japan, 73, 535-536, 1967.

Suzuk1, T. and S. HADA, Cretaceous tectonic mèlange of the Shimanto Belt in Shikoku, Japan, Geol. Soc. Japan, 85, 467-479, 1979.

TAIRA, A., M. TASHIRO, M. OKamura, and J. KatTo, The geology of the Shimanto Belt in Kochi Prefecture, Shikoku, Japan, in Geology and Paleontology of the Shimanto Belt (Selected Papers on Honor of Prof. J. Katto), edited by TAIRA, A. and M. TASHIRO, pp. 318-389, Rinyakosaikai Press, Kochi, Japan, 1980.

TERAOKA, Y., Comparison of the Cretaceous sandstones between the Shimanto terrane and the Median zone of Southwest Japan, with the reference to the provenance of the Shimanto geosynclinal sediments, Geol. Soc. Japan, 83, 795-810, 1977.

ToKUOKA, T. and F. KUMON, The Shimanto Terrain in the Akaishi Mountainland and the Kii Peninsula-a consideration on mineral composition of sandstones. Monograph, Nat. Sci. Mus., Tokyo, No. 12, 41-54, 1979. 
Errata "Stratigraphic change of the coarse clastic rocks "

\begin{tabular}{llll} 
page & \multicolumn{1}{c}{ line } & error & correction \\
820 & Fig. 1 caption & ingeous & igneous \\
822 & Fig. 3 caption & Kumon(1983 and & Kumon(1981 and \\
830 & 14 & model composition modal composition
\end{tabular}

